\title{
Effects of Paracetamol and Tenoxicam on Postoperative Pain and Need for Rescue Analgesia in Root Canal Treatments Performed Under General Anesthesia: A Retrospective Study
}

\author{
Genel Anestezi Altında Tamamlanan Kök Kanal Tedavilerinde Parasetamol \\ ve Tenoksikamın Postoperatif Ağrı Düzeyi ve Kurtarma Analjezisi \\ Gereksinimi Üzerine Etkisinin Değerlendirilmesi: Retrospektif Bir Araştırma
}

(1) Hicran Dönmez Özkan ${ }^{1}$, (1) Özlem Kocatürk ${ }^{2}$, (1) Pınar Açkurt Okutan ${ }^{1}$, (1) Senem Yiğit Özer ${ }^{1}$

${ }^{1}$ Aydın Adnan Menderes University Faculty of Dentistry, Department of Endodontics, Aydın, Turkey

${ }^{2}$ Aydın Adnan Menderes University Faculty of Dentistry, Department of Oral and Maxillofacial Surgery, Division of Anesthesiology, Aydın, Turkey

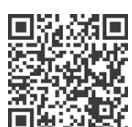

Keywords

General anesthesia, root canal treatment, paracetamol, postoperative pain, tenoxicam

Anahtar Kelimeler

Genel anestezi, kök kanal tedavisi, parasetamol, postoperatif ağrı, tenoksikam

Received/Geliş Tarihi : 08.03.2021

Accepted/Kabul Tarihi : 28.05.2021

doi:10.4274/meandros.galenos.2021.24892

Address for Correspondence/Yazışma Adresi: Hicran Dönmez Özkan Ph.D., Aydın Adnan Menderes University Faculty of Dentistry, Department of Endodontics, Aydın, Turkey

Phone : +902562133939

E-mail : hicrandonmez@hotmail.com

ORCID ID: orcid.org/0000-0002-4495-2746

(C) Meandros Medical and Dental Journal, Published by Galenos Publishing House.

This is article distributed under the terms of the

Creative Commons Attribution NonCommercial 4.0

International Licence (CC BY-NC 4.0).

\begin{abstract}
Objective: This study aimed to investigate the effects of parenterally administered paracetamol and tenoxicam on early postoperative pain regarding analgesia in healthy adults who had completed root canal treatments (RCTs) in a single visit under standard general anesthesia protocols.

Materials and Methods: In this retrospective study, the data of 83 adult patients who underwent RCTs under general anesthesia in a single visit due to severe nausea reflex and/or anxiety were analyzed. Patients were divided into two groups according to the intravenous administration of $15 \mathrm{mg} / \mathrm{kg}$ paracetamol ( $\mathrm{P}$ group) or $0.5 \mathrm{mg} /$ $\mathrm{kg}$ tenoxicam (T group) $30 \mathrm{~min}$ before the end of general anesthesia to meet their analgesia requirements. Thereafter, early postoperative period visual analog scale (VAS) scores were recorded at the $5^{\text {th }}$ minute after the patients were taken to the recovery room and at the subsequent $2^{\text {nd }}$ hour. After $2 \mathrm{~h}$, rescue analgesia was given to patients with VAS scores $>4$ in both groups and recorded. Data were analyzed statistically.

Results: A total of 68 patients who met the inclusion criteria were evaluated. Regarding postoperative pain values, the average VAS score was significantly lower in the $\mathrm{T}$ group at both the $5^{\text {th }}$ minute and $2^{\text {nd }}$ hour than in the $\mathrm{P}$ group. In both groups, the mean VAS scores were decreased by the same amount over time, and the differences between the groups were not significant $(p=0.452)$. Moreover, no significant difference was found between the two groups in terms of the need for rescue analgesia $(p=0.571)$.

Conclusion: Tenoxicam, administered parenterally, provides more effective analgesia for postoperative pain management compared with paracetamol when it is used in RCTs under general anesthesia.
\end{abstract}


Öz

Amaç: Bu çalışmanın amacı, standart genel anestezi protokolleri altında tek seansta kök kanal tedavileri tamamlanan sağlıklı erişkinlerde analjezi amacı ile parenteral uygulanan parasetamol ve tenoksikamın erken dönem postoperatif ağrı üzerine etkinliklerinin araştırılmasıdır.

Gereç ve Yöntemler: Bu retrospektif araştırmada, şiddetli bulantı refleksi ve/veya anksiyete sebebiyle genel anestezi altında kök kanal tedavileri tek seansta gerçekleştirilen 83 yetişkin hastanın verileri incelenmiştir. Hastalar, analjezi gereksinimlerinin sağlanması için genel anestezi sonlanmadan 30 dakika önce $15 \mathrm{mg} / \mathrm{kg}$ parasetamol (grup P) veya 0,5 mg/kg tenoksikamın (grup T) intravenöz olarak uygulanmasına göre iki gruba ayrılmıştır. Sonrasında, hastaların derlenme odasına alındıktan sonra 5. dakikadaki ve takip eden 2. saatteki erken postoperatif dönem vizüel analog skala (VAS) ölçümleri kayıt edilmiştir. Her iki grupta da 2 saat sonunda VAS skorları 4 üzerinde olan hastalara kurtarma analjezisi uygulanmış ve kayıt edilmiştir. Veriler istatistiksel olarak analiz edilmiştir.

Bulgular: Dahil edilme kriterlerini karşılayan toplam 68 hasta değerlendirmeye alınmıştır. Postoperatif ağrı değerleri açısından hem 5. dakikada hem de 2. saatte grup T'de grup P'ye göre istatistiksel olarak anlamlı olarak daha düşük VAS skor ortalamaları gözlenmiştir. Her iki grupta da VAS skor ortalamaları zamanla aynı ölçüde azaltmıştır ve gruplar arası fark istatistiksel olarak anlamlı değildir ( $p=0,452)$. Ayrıca, kurtarma analjezi intiyacı bakımından da iki grup arasında anlamlı fark görülmemiştir $(p=0,571)$.

Sonuç: Genel anestezi altında uygulanacak kök kanal tedavilerinde postoperatif ağrı yönetimi açısından parenteral olarak uygulanan tenoksikam, parasetamole kıyasla daha etkin analjezi sağlamaktadır.

\section{Introduction}

Dental anxiety is defined as an undescribable state of intense unease that develops due to fear and anxiety related to dental treatment (1). Today, despite the use of effective local anesthetic and analgesic drugs, many patients still have anxiety problems related to dental treatments $(2,3)$. In the treatment of dental anxiety, general anesthesia procedures are used when psychological approaches are not sufficient (4). General anesthesia is described as a situation in which a patient is rendered unconscious, completely or partially loses his protective reflexes, no responses to physical and verbal stimuli, airway patency cannot be achieved, and is connected to a respiratory support unit (1). Pain is the most common complication observed after operations performed under general anesthesia (5). Pharmacological, surgical and non-pharmacological methods are used in the management of postoperative pain (6). In pharmacological applications, drugs are precribed upon the request of a doctor and administered using different methods. The purpose of this method is the maximum relieve of pain with no or minimal side effects. Pain control with pharmacological methods aims to reduce the patient's pain in the postoperative period with narcotic and non-narcotic analgesics applied in the peroperative period. These protocols are determined by considering the type of surgery and individual characteristics and according to the expected pain intensity (6). In addition, it has been reported that effective management of postoperative pain after surgery ensures shortened recovery time and decreased duration of hospital stay (7). At the same time, effective analgesia provided to patients can prevent many complications that may develop $(8,9)$.

Restorations, endodontic treatments, periodontal and surgical procedures are performed under general anesthesia for children and adults with mental illness, anxiety problems, psychological disorders and severe nausea reflexes (10-12). Althoughrootcanal treatments (RCTs) under general anesthesia is technically difficult and time consuming, it is indicated for teeth that can remain functional (10). Postoperative pain after RCT is one of the most common complications $(13,14)$ and its incidence has been reported between 3 to 58\% (14). Although the main purpose of endodontic treatment is to produce appropriate biological results, it should be ensured that the patient does not feel pain during and after the treatment (14). Postoperative pain is as a result of many factors and its causes are divided into preoperative and procedural factors. Several factors such as the gender and age of the patient, the presence of systemic disease, the presence of preoperative pain, the condition of the pulp, the number of visits, and the use of intra-canal medication can affect postoperative pain (15). The management of postoperative pain after RCT is multifactorial and includes the combination of a good endodontic procedure and appropriate use of analgesics. Most of the drugs used to manage postendodontic pain consist of non-narcotic analgesics including paracetamol, 
non-steroidal anti-inflammatory drugs (NSAIDs) and narcotic analgesics (16).

Paracetamol is an analgesic agent that is thought to have an effect on the central nervous system through central cyclooxygenase (COX) inhibition and is thought to have a significant effect on platelet aggregation (17). On the other hand, tenoxicam is a NSAID that can be used reliably with minimal hematological side effects, has a long half-life and sufficient analgesic effect. Due to the low incidence of side effects, these two analgesic drugs are agents used in outpatient surgical procedures (18).

RCTs completed under general anesthesia are performed in single visit. There are few studies evaluating postoperative pain in dental procedures completed under general anesthesia $(19,20)$. However, management of early postoperative pain in endodontic treatments performed under general anesthesia has never previously been investigated in the literature. Therefore, the aim of this study was to investigate the effects of parenterally administered paracetamol and tenoxicam on early postoperative pain in healthy adults under standard general anesthesia protocols for analgesia. The null hypotheses of the present study are as follows;

1. There was no difference between the paracetamol and tenoxicam groups in healthy adults undergoing RCTs under general anesthesia on early postoperative pain.

2. There was no difference between the groups in terms of the need for rescue analgesia after the administration of paracetamol and tenoxicam.

\section{Materials and Methods}

This study was conducted with an approval from the Non-Invasive Clinical Research Ethics Committee (protocol no: 2020/75, date: 02.07.2020) of the Faculty of Medicine Aydın Adnan Menderes University. This retrospective study was carried out by scanning the files of 83 adult patients between the ages of 18-60 who were referred to Faculty of Dentistry, Aydın Adnan Menderes University, during a threeyear period between January 2016 and December 2018. Patients were only limited to have performed endodontic and restorative treatments under general anesthesia. Inclusion and exclusion criteria are presented in Table 1. Before the general anesthesia consents forms stating that the patients data can bu used in the scientific research were signed by the patients.

\section{Preoperative Evaluation}

Routine hemogram, blood glucose, liver enzymes, kidney function tests, blood electrolyte values, coagulation markers were evaluated for all patients to be treated in the operating room. Patients who had no issues in physical examination and blood tests were approved for procedures under general anesthesia. Each patient was made to observe at least an 8 hours fasting period prior to the operation. IV vascular access was established for patients on the day of operation. Routine vital signs of the patients and preoperative period anxiety levels were recorded according to Beck Anxiety scale. Beck Anxiety scale is an index with questions scaling up to 63 points. Patients' anxiety levels were determined as; 0-7 points: no anxiety, 8-15 points: mild anxiety, $16-25$ points: moderate anxiety, 26-63 points: severe anxiety.

After determining the anxiety levels of the patients, midazolam at a dose $0.04-0.05 \mathrm{mg} / \mathrm{kg}$ (maximum dose not exceeding $4 \mathrm{mg}$ ) was administered as IV 15 minutes before the surgery for premedication, All preoperative practices are routine clinical procedures specified in the files.

\section{General Anesthesia Procedure}

A routine general anesthesia protocol was applied to all patients who came to the General Anesthesia Unit. All patients were preoxygenated with a face mask after their monitorization. The same anesthesiologist (Ö.Ö.) with 10 years of clinical experience performed all of the procedures. Fentanyl $1-2 \mu \mathrm{g} \cdot \mathrm{kg}^{-1} \mathrm{IV}$, propofol 2-2.5 mg. kg-1 IV and rocuronium 0.5-0.6 $\mu \mathrm{g} \cdot \mathrm{kg}^{-1} \mathrm{IV}$ were administered for induction. One minute after unconsciousness and respiratory suppression, nasal intubation was performed with a flexible spiral tube. In the maintenance of anesthesia, 1.5-2\% sevoflurane was used in a mixture of $\mathrm{N}_{2} \mathrm{O} 1.0 \mathrm{~L} / \mathrm{min}$, $\mathrm{O}_{2} 1.0 \mathrm{~L} / \mathrm{min}$. Rocuronium $0.15-0.2 \mathrm{mg} \cdot \mathrm{kg}^{-1} \mathrm{IV}$ bolus was administered as an additional muscle relaxant. Metoclopramide $0.2 \mathrm{mg} . \mathrm{kg}^{-1} \mathrm{IV}$ was administered to each patient as an antiemetic before the end of general anesthesia. All intraoperative practices are routine procedures specified in the files.

\section{Endodontic Treatment Procedure}

All endodontic treatment procedures in this study were performed in a single session under general 
anesthesia by endodontists with at least 5 years of experience. Root canal lengths were determined with the help of an endodontic apex finder (VDW, München, Germany) after opening the entrance cavity under rubberdam isolation. All canals were preformed with K-type hand files (DiaDent, Cheongju, Korea). The root canals were then shaped by applying the recommended file sequence with the Protaper Next rotary file system (ProTaper Next; Dentsply Sirona, Ballaigues, Switzerland) at the torque and speeds recommended by the manufacturer. Between each file, $2 \mathrm{~mL}$ of irrigation with $2.5 \% \mathrm{NaOCl}$ was made, and in total, each channel was irrigated with at least $12 \mathrm{~mL}$ of $\mathrm{NaOCl}$. For final irrigation, $2 \mathrm{~mL}$ of $17 \%$ EDTA, $2 \mathrm{~mL}$ of $2.5 \% \mathrm{NaOCl}$ and $2 \mathrm{~mL}$ of distilled water was applied to each root canal, respectively. The root canals were then dried with sterile paper cones and filled with epoxy resin-containing root canal sealer (AH Plus; Dentsply DeTrey, Konstanz, Germany) and Gutta-percha cones (Dentsply Sirona) using a single cone technique. Teeth whose RCTs were completed were permanently restored using a single-stage selfadhesive (Tokuyama Bond Force, Tokuyama Dental, Tokyo, Japan) and light-cured composite restoration material (Clearfil Majesty, Kuraray, Tokyo, Japan).

\section{Analgesia Dose}

As a routine analgesia protocol, $15 \mathrm{mg} / \mathrm{kg}$ paracetamol or tenoxicam $0.5 \mathrm{mg} / \mathrm{kg}$ was administered intravenously 30 minutes before the end of general anesthesia to patients who underwent dental treatments under general anesthesia in our operating room. The choice of tenoxicam or paracetamol was made according to the availability of the drugs in the hospital pharmacy during the study period. In the recovery unit, the postoperative pain levels of the patients were routinely assessed using a $10 \mathrm{~cm}$ visual analog scale (VAS) (beginning from -0- "no pain", to the other end -10- "unbearable pain"). In addition, the patients were followed in terms of other expected side effects and their data were recorded in the patient files (nausea, vomiting, gastric burning and/or pain, rash, allergic reaction, bleeding). Patients with VAS> 4 are given $0.5 \mathrm{mg} / \mathrm{kg}$ tramadol as rescue analgesia as mentioned in the studies of Niemi-Murola et al. (21) and Gupta et al. (22). These informations were recorded in the patient files.

Patients treated with paracetamol were sorted into group $\mathrm{P}$ and patients given tenoxicam in group T. Early postoperative VAS measurements were recorded at the $5^{\text {th }}$ minute and subsequently at $2^{\text {nd }}$ hour after the patients in both groups were taken to the recovery room. The patients' initial anxiety levels, demographic data, number of teeth treated with RCT, duration of general anesthesia, postoperative pain VAS values and rescue analgesia requirements were statistically evaluated.

\section{Statistical Analysis}

IBM SPSS version 25.0 (IBM, New York, NY, USA) package program was used for the analysis of the data obtained in this study. Shapiro-Wilk test, kurtosisskewness values and histogram graphics were used to test the compliance of the data of the study to normal

\begin{tabular}{|c|c|}
\hline Inclusion criteria & Exclusion criteria \\
\hline $\begin{array}{l}\text { Patients between the ages of } 18-60 \text { and who were physically } \\
\text { and/or mentally healthy } \\
\text { Patients who consented to the use of their data in research }\end{array}$ & $\begin{array}{l}\text { Patients who did not consent to and/or from whom consent was } \\
\text { not obtain for the use of their data in research }\end{array}$ \\
\hline $\begin{array}{l}\text { Patient in the I-II group of the ASA (American Society of } \\
\text { Anesthesiologists) }\end{array}$ & Mentally unhealthy and ASA III-IV group patients \\
\hline Patients undergoing a routine general anesthetic procedure & $\begin{array}{l}\text { Patients undergoing treatments other than routine general } \\
\text { anesthesia procedures }\end{array}$ \\
\hline \multirow[t]{3}{*}{$\begin{array}{l}\text { Patients who have completed at least one root canal treatment } \\
\text { in a single visit during general anesthesia }\end{array}$} & $\begin{array}{l}\text { Patients who have undergone surgical, periodontal and/or } \\
\text { prosthetic procedures together with endodontic procedures } \\
\text { during general anesthesia. }\end{array}$ \\
\hline & $\begin{array}{l}\text { Patients allergic to paracetomal } \\
\text { Patients allergic to non-steroidal anti-inflammatory agents and/or } \\
\text { have a history of asthma }\end{array}$ \\
\hline & $\begin{array}{l}\text { Patients who had pain in the preoperative period and/or used } \\
\text { painkillers at least } 3 \text { days before the operation }\end{array}$ \\
\hline
\end{tabular}


distribution. Descriptive statistics were used to analyze demographic data. Repeated measures ANOVA test was used to evaluate VAS scores according to groups and measurement times. At the end of the $2^{\text {nd }}$ hour, whether there was a difference between NSAIDs in terms of the number of patients with a VAS score of 4 and above was examined by Fisher's Exact chi-square test.

\section{Results}

In the specified time range, 11 out of 83 adult patients who underwent RCT under general anesthesia were excluded from the study because they did not meet the inclusion criteria. Of the

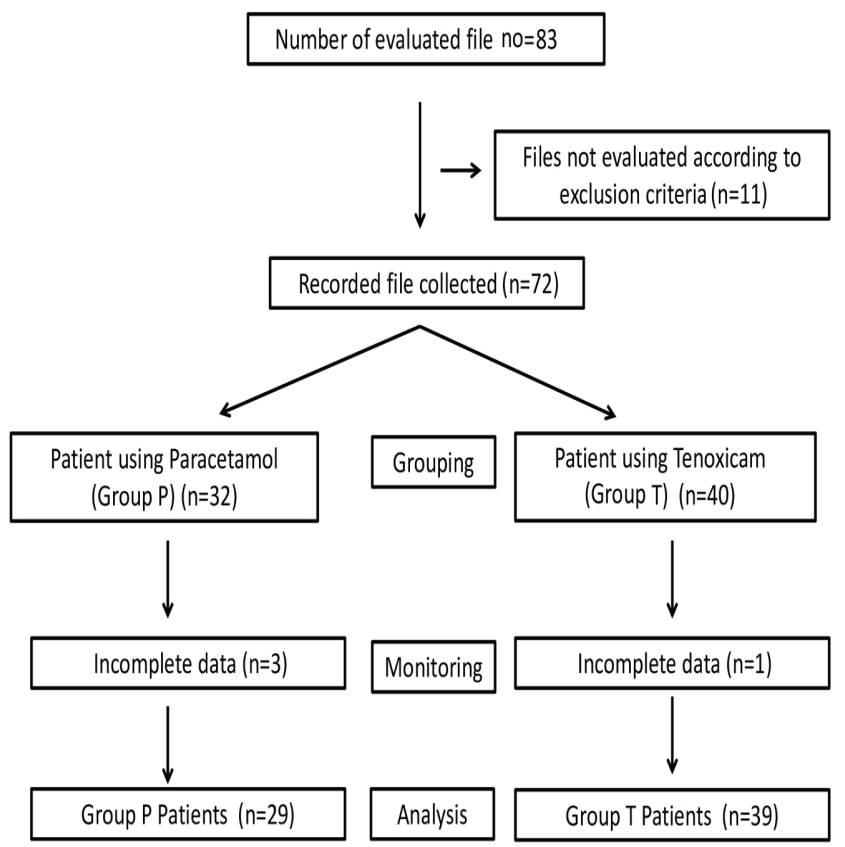

Figure 1. Flow chart of the participants remaining 72 patients, 32 were sorted into group $P$, 40 patients in group $T$. Three patients from group $P$ and 1 patient from group $T$ were excluded from the study due to missing data in their files. As a result, the data of 29 patients in group $P$ and 39 patients in group $T$ (68 patients in total) were analyzed (Figure 1). Demographic variables and clinical characteristics of the patients are as shown in Table 2. The number and the types of the treated teeth in the groups are as shown in Table 3.

No statistically significant difference was found between group $\mathrm{T}$ and group $\mathrm{P}$ in terms of demographic data, American Society of Anesthesiologists scores, duration of intraoperative anesthesia, and the number of teeth treated during RCT ( $p>0.05$ ) (Table 2).

There was no difference between the averages of Beck Anxiety scores in the preoperative period in both groups, and both groups were found to have mildmoderate preoperative anxiety scores (Table 4).

In terms of postoperative pain values at $5^{\text {th }}$ minute (VAS 1), statistically significant lower VAS scores were observed in group $T$ compared to group $P(p=0.010)$ (Table 4). Similarly, in the postoperative pain values at the $2^{\text {nd }}$ hour (VAS 2), statistically significantly lower VAS score averages were observed in group $T$ compared to group $P(p=0.019)$ (Table 4). Considering the differences in change over time, the effect of drugs on the mean of VAS score over time in both group $P$ and group $T$ was not statistically significant $(p=0.452)$. Both drugs decreased the VAS score to the same extent over time (Figure 2). However, there was no significant difference between group $T$ and group $P$ in terms of rescue analgesia need $(p=0.571)$ (Table 4).

Postoperative side effects were observed in 2 patients in group $T$ (nausea-vomiting), in 1 patient in group $\mathrm{P}$ (mild epistaxis due to nasotracheal

\begin{tabular}{|l|l|l|l|}
\hline \multicolumn{2}{|l|}{ Table 2. Demographic data and intraoperative characteristics } & $\mathbf{p}$ \\
\hline Age & Tenoxicam & Paracetamol & 0.665 \\
\hline Gender (f/m) (n) & $31.10 \pm 10.87$ & $30.17 \pm 11.91$ & 0.808 \\
\hline Weight $(\mathrm{kg})$ & $21 / 18$ & $14 / 15$ & 0.691 \\
\hline Anesthesia duration & $72.07 \pm 10.25$ & $73.00 \pm 10.40$ & 0.960 \\
\hline Number of tretaed teeth & $234.74 \pm 51.70$ & $238.10 \pm 52.54$ & 0.925 \\
\hline ASA I/II (n) & $1.79 \pm 0.97$ & $1.75 \pm 0.83$ & 0.940 \\
\hline *Mean \pm standard deviation. F: Female, m: Male, ASA: American Society of Anesthesiologists & $24 / 5$ & \\
\hline
\end{tabular}


intubation), and in 2 patients in group $\mathrm{P}$ (headache). No side effects were observed in other patients.

\section{Discussion}

According to the findings of the present study, it was observed that significantly lower postoperative pain values were observed in both early period measurements ( 5 minutes and 2 hours after) in patients who received tenoxicam in endodontic treatments performed under general anesthesia compared to those who received paracetamol. Therefore, the first null hypothesis was rejected. Since, there was no statistically significant difference between the two groups in terms of the need for rescue analgesia, the second null hypothesis should be accepted.

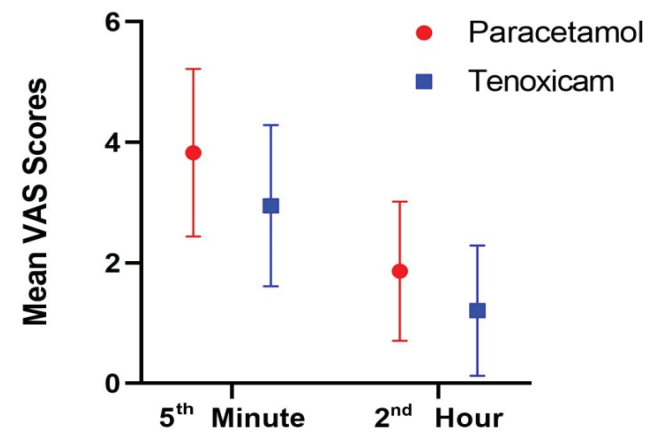

Figure 2. The distribution of mean VAS scores between groups for checked time periods

VAS: Visual analog score
Pain is a condition that is oftentimes more important than the disease itself and often needs to be treated quickly (23). Since the most common clinical complication after RCT is pain (14), there are many studies in the literature on the management of pain after RCT $(24,25)$; however, there is no study in the literature regarding the management of early pain after RCT under general anesthesia. Therefore, the results of the present study may highlight major issues in the literature. While intra-operative pain is prevented in endodontic treatments with effective local anesthesia methods and operative techniques, paracetamol, non-narcotic analgesics containing NSAIDs and narcotic analgesics are being used in postoperative pain management $(16,24,25)$. An IV analgesic may be the preferred choice for patients who are unable to take drugs administered orally in the early postoperative period after general anesthesia and need rapid onset of analgesia (26). Tenoxicam is a NSAID with high potential in terms of its analgesic and anti-inflammatory effects, and due to its possible use in IV form, it is frequently preferred after surgical procedures under general anesthesia where oral administeration is not possible. Due to its long halflife and the sufficiency of a single dose tenoxicam has moved to the forefront in postoperative pain control for outpatient surgeries compared to other NSAI groups (27). Regarding these reasons, tenoxicam was chosen as an NSAID in the present study. However,

Table 3. The number and types of the treated teeth in the groups

\begin{tabular}{|l|l|l|l|l|}
\multirow{2}{*}{} & \multicolumn{2}{|c|}{ Paracetamol } & \multicolumn{2}{c}{ Tenoxicam } \\
\cline { 2 - 6 } & Maxilla (n) & Mandible (n) & Maxilla (n) & Mandible (n) \\
\hline Incisors & 9 & 5 & 11 & 8 \\
\hline Premine & 8 & 3 & 9 & 9 \\
\hline Molars & 7 & 6 & 10 & 7 \\
\hline Sum & 6 & 8 & 9 & 10 \\
\hline
\end{tabular}

Table 4. Visual analog scores and anxiety levels

\begin{tabular}{|l|l|l|l|}
\hline & Tenoxicam & Paracetamol & $\mathbf{p}$ \\
\hline VAS $1\left(5^{\text {th }}\right.$ minute $)$ & $2.94 \pm 0.21$ & $3.82 \pm 0.25$ & $0.010^{*}$ \\
\hline VAS $2\left(2^{\text {nd }}\right.$ hour $)$ & $1.20 \pm 0.75$ & $1.86 \pm 0.20$ & $0.019^{*}$ \\
\hline Rescue analgesia need & 1 & 2 & 0.571 \\
\hline Anxiety level ${ }^{\beta}$ & $14.69 \pm 0.17$ & $16.24 \pm 6.60$ & 0.452 \\
\hline Mean \pm standard deviation. ${ }^{*} p \leq 0.05,{ }^{B}$ Total anxiety score according to the Beck Anxiety scale. VAS: Visual analog score \\
\hline
\end{tabular}


NSAIDs have some undesirable side effects on many body systems, especially the gastrointestinal system, as well as their proven analgesic effects, reducing platelet aggregation and prolonging the bleeding time (28).

Paracetomol is also an another agent which can be administered intravenously, has a proven analgesic efficacy and less side effects compared to NSAIDs $(26,29)$, hence it is an another agent of choice in pain control after endodontic treatment. Cheung and Rodrigo (30) used a single oral dose of $40 \mathrm{mg}$ tenoxicam and 1,000 $\mathrm{mg}$ paracetamol in 30 dental surgery cases and reported that both drugs provided similar postoperative analgesia. Similar to our results, it has been reported that when administered as IV, tenoxicam provides an effective analgesia at doses of $20 \mathrm{mg}$ and $40 \mathrm{mg}$ especially after oral surgeries (29). Likewise, Gunusen et al. (31) reported that IV tenoxicam reduced both postoperative pain and additional need of morphine compared to paracetamol in abdominal hysteroctomy cases. However, unlike these studies, there are also studies that have found a superior postoperative efficiency with paracetamol (32). Hyllested et al. (32) argued that paracetamol is an appropriate alternative to NSAIDs, especially due to its low incidence of side effects, and that it should be a preferred option in high-risk patients. Khalili et al. (33) reported that there was no difference between paracetamol use alone and combined use of paracetamol with oxicam group NSAIDs especially in orthopedic operations. We are of the opinion that these different findings in analgesic efficacy comparison studies may be due to different surgery types.

In the present study, no significant side effects were observed due to the use of either paracetamol or tenoxicam. In the literature, there are different interpretations about side effects as well as increased analgesia efficacy regarding the use of both groups of drugs separately and in combination. Hyllested et al. (32) stated that combining paracetamol with NSAIDs may be appropriate due to the increased analgesic efficacy, but attention should be paid to the potential increase in side effects resulting from their combined use. The risk increases especially in longterm use without lowering the dose. Ong et al. (34) reported that the combination of long-acting NSAIDs such as paracetamol and tenoxicam theoretically has the disadvantage of pharmacokinetic incompatibility because tenoxicam has a much longer elimination half-life than paracetamol. On the other hand, Merry et al. (35) stated that the combination of NSAID and paracetamol minimizes the need for rescue analgesia and the side effects caused by opioid use. It is known that there is a relationship between plasma paracetamol concentrations and analgesic efficacy. Attempting to continually maintain paracetamol plasma concentrations may cause the dose to be increased above the required threshold during postoperative follow-up, increasing the risk of hepatotoxicity.

The most important limitation of this study is the small sample size. Surgical, prosthetic and periodontological procedures, which may effect postoperative pain, were also performed in patients who underwent dental procedures under general anesthesia, often with endodontic treatments. As a result, the population of the study was limited due to the exclusion of these processes.

The incidence of post operative pain after RCT has been associated with various factors in the literature such as age, gender, pulpal and periradicular status, tooth type, preoperative pain, sinus tracts, and operational factors $(36,37)$. For his reasons, many factors such as tooth type, pulp and periradicular status of the patient have been tried to be standardized in studies related to postoperative pain after canal treatment in the literature $(13,14,36,37)$. However, as stated above, the most important limitation of this study is its small sample size. Therefore, due to the limited number of patients evaluated in this study, standardization of other factors had to be ignored. Therefore, this issue is another limitation of this study. Consequently, we think that the results of this study should be reconfirmed in larger patient populations with new studies.

\section{Conclusion}

As a result, IV tenoxicam provides more effective postoperative analgesia than IV paracetomol in the management of postoperative pain after RCTs performed in single visit under general anesthesia. In addition, since there is no difference between the two drugs in terms of rescue analgesia frequency and paracetomol has less side effects than NSAIDs, it makes IV paracetomal administration preferable in RCT treatments under general anesthesia. 


\section{Ethics}

Ethics Committee Approval: This study was conducted with an approval from the Non-Invasive Clinical Research Ethics Committee (protocol no: 2020/75, date: 02.07.2020) of the Faculty of Medicine Aydın Adnan Menderes University.

Informed Consent: Retrospective study.

Peer-review: Externally peer-reviewed.

\section{Authorship Contributions}

Concept: H.D.Ö., Ö.K., S.Y.Ö., P.A.O., Design: Ö.K., H.D.Ö., Supervision: Ö.K., H.D.Ö., Fundings: H.D.Ö., Ö.K., S.Y.Ö., P.A.O., Materials: H.D.Ö., P.A.O., Ö.K., Data Collection or Processing: Ö.K., Analysis or Interpretation: Ö.K., Literature Search: Ö.K., H.D.Ö., Writing: Ö.K., H.D.Ö., Critical Review: S.Y.Ö., P.A.O.

Conflict of Interest: No conflict of interest was declared by the authors.

Financial Disclosure: The authors declared that this study received no financial support.

\section{References}

1. Köroğlu A, Durkan R. An evaluation of the etiology and the treatment procedures of dental anxiety syndrome encountered in dental applications. J Dent Fac Atatürk Uni 2010; 2010: 20512.

2. Erten H, Akarslan ZZ, Bodrumlu E. Dental fear and anxiety levels of patients attending a dental clinic. Quintessence Int 2006; 37: 304-10.

3. Firat $D$, Tunc EP, Sar V. Dental anxiety among adults in Turkey. J Contemp Dent Pract 2006;7:75-82.

4. Ay $S$, Öztürk M. Bilinçli sedasyon. Cumhuriyet Dental Journal 2000; 3: 121-6.

5. Baygin O, Tuzuner T, Isik B, Kusgoz A, Tanriver M. Comparison of pre-emptive ibuprofen, paracetamol, and placebo administration in reducing post-operative pain in primary tooth extraction. Int J Paediatr Dent 2011; 21: 306-13.

6. Strassels SA, McNicol E, Suleman R. Postoperative pain management: a practical review, part 1. Am J Health Syst Pharm 2005; 62: 1904-16.

7. Forrest JB, Heitlinger EL, Revell S. Ketorolac for postoperative pain management in children. Drug Saf 1997; 16: 309-29.

8. Çetin N, Eşer İ. Hasta kontrollü analjezi yöntemine ilişkin verilen hasta eğitiminin postoperatif ağrının giderilmesine etkisinin incelenmesi. Ege Üniversitesi Hemşirelik Fakültesi Dergisi 2006; 22: 15-25.

9. Pasero C, McCaffery M. When patients can't report pain. Assessing patients with communication difficulties. Am J Nurs 2000; 100: 22-3.

10. Linas N, Faulks D, Hennequin M, Cousson PY. Conservative and endodontic treatment performed under general anesthesia: A discussion of protocols and outcomes. Spec Care Dentist 2019; 39: 453-63.

11. Çağıran EY, Efeoğlu C, Balcıoğlu T, Koca H. Mental retarde hastalarda dental tedavi: Retrospektif inceleme. Turkiye Klinikleri J Med Sci 2011; 31: 830-6.

12. Özkan AS, Erdoğan MA, Şanlı M, Kaçmaz O, Durmuş M, Çolak C. Retrospective Evaluation of Dental Treatment under General Anaesthesia. Turk J Anaesthesiol Reanim 2015; 43: 332-6.

13. Gondim E Jr, Setzer FC, Dos Carmo CB, Kim S. Postoperative pain after the application of two different irrigation devices in a prospective randomized clinical trial. J Endod 2010; 36: 1295301.

14. Sathorn C, Parashos $P$, Messer $H$. The prevalence of postoperative pain and flare-up in single- and multiple-visit endodontic treatment: a systematic review. Int Endod J 2008; 41: 91-9.

15. Torabinejad M, Kettering JD, McGraw JC, Cummings RR, Dwyer TG, Tobias TS. Factors associated with endodontic interappointment emergencies of teeth with necrotic pulps. J Endod 1988; 14: 261-6.

16. Kaya Üreyen $K$, Çiçek $E$, Aşçı $H$. Endodontide ağrı ve analjezik kullanımı. SDÜ Sağlık Bilimleri Dergisi 2013; 4: 39-45.

17. Unal SS, Aksoy M, Ahiskalioglu A, Erdem AF, Adanur S. The effect of intravenous preemptive paracetamol on postoperative fentanyl consumption in patients undergoing open nephrectomy: a prospective randomized study. Niger J Clin Pract 2015; 18: 6874.

18. İnal MA, Baran I, Polat R, Özlü O. Laparoskopik kolesistektomi cerrahisinde anestezi indüksiyonu sonrası verilen deksketoprofen trometamol ve tenoksikamın postoperatif tramadol tüketimi üzerine etkilerinin karşılaştrılması. Türkiye Klinikleri J Anest Reanim 2016; 14: 7-13.

19. Needleman HL, Harpavat S, Wu S, Allred EN, Berde C. Postoperative pain and other sequelae of dental rehabilitations performed on children under general anesthesia. Pediatr Dent 2008; 30: 111-21.

20. Wong M, Copp PE, Haas DA. Postoperative Pain in Children After Dentistry Under General Anesthesia. Anesth Prog 2015; 62: 14052.

21. Niemi-Murola L, Pöyhiä R, Onkinen K, Rhen B, Mäkelä A, Niemi TT. Patient satisfaction with postoperative pain management-effect of preoperative factors. Pain Manag Nurs 2007; 8: 122-9.

22. Gupta R, Bogra J, Verma R, Kohli M, Kushwaha JK, Kumar S. Dexmedetomidine as an intrathecal adjuvant for postoperative analgesia. Indian J Anaesth 2011; 55: 347-51.

23. Alaçam T, Görgül G, Darendeliler S, Bala O. Endodontik tedavi sonrası ağrı kontrolünde naproksen sodyumun kullanılması. GÜ Dişhek Fak Derg 1991; 8: 1-19.

24. Wells LK, Drum M, Nusstein J, Reader A, Beck M. Efficacy of Ibuprofen and ibuprofen/acetaminophen on postoperative pain in symptomatic patients with a pulpal diagnosis of necrosis. J Endod 2011; 37: 1608-12.

25. Fuller M, Younkin K, Drum M, Reader A, Nusstein J, Fowler S. Postoperative Pain Management with Oral Methylprednisolone in Symptomatic Patients with a Pulpal Diagnosis of Necrosis: A 
Prospective Randomized, Double-blind Study. J Endod 2018; 44: 1457-61.

26. Jarde $\mathrm{O}$, Boccard $\mathrm{E}$. Parenteral versus oral route increases paracetamol efficacy. Clin Drug Invest 1997; 14: 474-81.

27. O'Hanlon DM, Thambipillai T, Colbert ST, Keane PW, Given HF. Timing of pre-emptive tenoxicam is important for postoperative analgesia. Can J Anaesth 2001; 48: 162-6.

28. Şentürk T. Non-Steroid anti-inflamatuvar ilaçlar (NSAii). İç Hastalıkları Derg 2014; 2: 490-5.

29. Day RO, Graham GG, Whelton A. The position of paracetamol in the world of analgesics. Am J Ther 2000; 7: 51-4.

30. Cheung LK, Rodrigo C. Tenoxicam for pain relief following third molar surgery. Anesth Pain Control Dent 1992; 1: 229-33.

31. Gunusen I, Karaman S, Acar A, Sargin A, Firat V. The efficacy of paracetamol versus tenoxicam on postoperative pain and morphine consumption after abdominal hysterectomy: a placebo-controlled, randomized study. Clin Exp Obstet Gynecol 2012; 39: 49-52.

32. Hyllested M, Jones S, Pedersen JL, Kehlet H. Comparative effect of paracetamol, NSAIDs or their combination in postoperative pain management: a qualitative review. $\mathrm{Br} J$ Anaesth 2002; 88: 199-214.
33. Khalili G, Salimianfard M, Zarehzadeh A. Comparison between paracetamol, piroxicam, their combination, and placebo in postoperative pain management of upper limb orthopedic surgery (a randomized double blind clinical trial). Adv Biomed Res 2016; 5: 114.

34. Ong CK, Seymour RA, Lirk P, Merry AF. Combining paracetamol (acetaminophen) with nonsteroidal antiinflammatory drugs: a qualitative systematic review of analgesic efficacy for acute postoperative pain. Anesth Analg 2010; 110: 1170-9.

35. Merry AF, Swinburn PF, Middleton NG, Edwards JL, Calder MV. Tenoxicam and paracetamol-codeine combination after oral surgery: a prospective, randomized, double-blind, placebocontrolled study. Br J Anaesth 1998; 81: 875-80.

36. Ng YL, Glennon JP, Setchell DJ, Gulabivala K. Prevalence of and factors affecting post-obturation pain in patients undergoing root canal treatment. Int Endod J 2004; 37: 381-91.

37. Ng YL, Mann V, Gulabivala K. A prospective study of the factors affecting outcomes of nonsurgical root canal treatment: part 1: periapical health. Int Endod J 2011; 44: 583-609. 